\title{
The Values of Social Education in the Qur'an and its Relevance to The Social Character Building For Children
}

\author{
Athoillah Islamy \\ Institut Agama Islam Negeri Pekalongan \\ Saihu \\ Pascasarjana Perguruan Tinggi Ilmu Qur'an Jakarta
}

\begin{abstract}
This study aims to find the values of social educational contained in the Qur'an. This research is a qualitative research in the form of library research. The focus of the verse is the object and source of primary data of this study, namely various commentaries that explain Surah at-Taubah verses 71-72. While secondary data sources of research is various literatut that are relevant to the subject matter of discussion. To answer the discussion of the research, the writer uses the method of interpretation maudhu'i (thematic). This study concludes that the values of humanistic social education contained in the letter atTaubah verses 71-72 include attitudes of helping to help, an invitation to the good and preventing munkar, social solidarity, brotherhood. These values can be a spirit of social education in forming empathy, mutual care, protection, tolerance and high social solidarity. The four values of social education can be actualized in the context of the planting of social education in children through various things, among others, the cultivation of a noble mentality in children can be realized in the planting of brotherly values and help children. Furthermore, the cultivation of a spirit of attention to the rights of others and a commitment to social ethics can be realized through the inculcation of the value of social solidarity. Then, inculcation of critical and social supervision can be realized by instilling the value of amar makruf nahi munkar.
\end{abstract}

Keywords: Value, social education, Qur'an, character building, children 


\section{Introduction}

Education can not be separated in human social life, both in family life, and in the life of the nation and state. ${ }^{1}$ This is because education is the foundation in building the nation's civilization. $^{2}$ Therefore, educational values are expected to be able to deliver human functions in civilization. ${ }^{3}$ From this it can be understood that the values of social education are important elements in realizing the civilization of the social life of society.

The existence of education as a process of humanization in the context of life can be found in the Islamic education system that is built on the basis of humanistic values. This is due to Islam making the human dimension as its educational orientation. ${ }^{4}$ In Islam itself, the existence of humanistic social education is an urgent matter in fostering pluralistic and heterogeneous community life. ${ }^{5}$ This is as an implicit explanation in Surah Al-Hujurat verse: 13 which commands humans to be able to present the values of goodness among human beings in the context of a pluralistic and heterogeneous social life. Therefore, the process of humanistic social education is important in the context of social life. ${ }^{6}$ From this it can be understood that in Islam, the existence of humanistic social education values becomes the concept or model of education that can be found its theological basis in the Qur'an

${ }^{1}$ Hamid Harmadi, Pengantar Pendidikan Era Globalisasi, ed. oleh Masri Sarep Putra (AnImage, 2016), 18.

${ }^{2}$ In the Indonesian context there is a juridical basis, namely Law No. 20 of 2003 which explains that education is a conscious and planned effort to create an atmosphere of learning and learning process so that students actively develop their potential so that they have spiritual strength, self-control, personality, intelligence, noble morals, and the skills needed by himself, society, nation and state. Read Law Number 20, 2003.

${ }^{3}$ Masdub, Sosiologi Pendidikan Agama Islam (Yogyakarta: Aswaja Pressindo, 2015), 39.

4 Arbayah, :Model Pembelajaran Humanistik," Dinamika Ilmu, Vol 13. No. 2 (2013), 205.

${ }^{5}$ Masdub, Sosiologi Pendidikan Agama Islam, ed. oleh Abdul Khaliq (Yogyakarta: Aswaja Pressindo, 2015), 142.

${ }^{6}$ Halid Hanafi, La Adu, Ilmu Pendidikan Islam, 16. 
Considering the Qur'an as the main theological foundation that guides the life of Muslims, in this study, the author is interested in exploring the values of humanistic social education in the Qur'an. In this case, the main object of the verse that will be the focus of research is the letter at-Taubah verses 71-72 and its relevance to the social character building for children

\section{Discussion}

\section{Discourse On Social Education}

There is an explanation of the terminology of educational leaders in explaining what is meant by education. John Dewey states that education is the process of forming fundamental skills, emotional toward nature, and fellow human beings. Then M.J. Langeveld argues that education is an effort, influence, protection and assistance given to children in order to aim at maturity. Frederick J. McDonald also explained that education is a process or activity that is directed at changing human behavior. ${ }^{7}$ From these various explanations it can be understood that education is a process of forming mental human systematically.

Then what is meant by social education. In this case there are also explanations from the figures. According to $\mathrm{S}$. Hamidjoyo, social education is a process for educating, fostering, guiding, developing individuals in their social and natural environment so that they can be responsible and become a driver towards change and progress. ${ }^{8}$ Furthermore, Nasih Ulwan explained social education as education in forming good social ethics based on theological foundation. ${ }^{9}$ According to Muhammad Rifa'i, the purpose of social education is to analyze the process of socialization of children, both in the context of the family, school and community. Rifa'i added that the

${ }^{7}$ Amos Neolaka, Landasan Pendidikan (Depok: PT Kharisma Putra Utama, 2017), 11.

${ }^{8}$ Soeleman Joesoef, Konsep Dasar Pendidikan Luar Sekolah (Jakarta: Bumi Aksara, 1992), 100.

${ }^{9}$ Abdullah Nashih Ulwan, Pendidikan Anak dalam Islam (Jakarta: Pustaka Amani, 2002), 435. 
influence of the environment and culture of the community on the personal development of children is something that must be considered. ${ }^{10}$ In its application, Fraenkel as quoted by Fardus explained that there are several ways to construct social values in a person, among others as follows .. First, strive for someone to recognize and accept values as their own and be responsible for the decisions they make. Second, emphasizing that someone can use the ability to think logically and scientifically in analyzing social problems related to certain values. Third, raise awareness and develop one's ability to be able to identify their own values and the values of others. Fourth, develop one's ability to do social activities. ${ }^{11}$

Based on the description above, it can be understood that social education is a conscious, deliberate and systematic effort in shaping individuals in order to develop and practice social attitudes and behavior in a good and noble manner within the community in accordance with their rights and obligations in social life.

The Urgency of Character Building for children

It is important to realize and understand that the formation of a child's character begins with family education as an early stage in which a child knows his environment. From the family a child is introduced to behave in accordance with the values of goodness and norms that should be done. Thus, the family represents the community in preparing the generation that will carry on the culture. Meanwhile, the formation of character in the family and community occurs through supervision and control of children as individuals who are carried out with daily habits, so that it is expected to grow in the values adopted and expected by families and communities. Furthermore, character education is explicitly carried out at every level of school

\footnotetext{
${ }^{10}$ Muhammad Rifa'i, Sosiologi Pendidikan (Jogjakarta: ArRuzz Media, 2011), 95.

${ }^{11}$ Fardus, "Model Pendidikan Nilai Sosial Budaya dalam Keluarga dan Lingkungan Manusia Bajo di Bajo," Educationist, Vol. IV No. 1 (2010), 58.
} 
education involving all components in the school. ${ }^{12}$ From this it can be understood that the support or motivation of various parties in the formation of children's character is something that cannot be ignored. This is because motivation is an important element that is a driving force for humans to act, behave or try to realize the goals that have been determined. ${ }^{13}$

The implementation of character education for children at the school level can be carried out in various ways, from customizing positive behavior in the school environment to incorporating character values into the learning process. Thus it is expected that through character education that is applied can equip students early, so they have good character and can be an example for the next generation. With character education can also equip students to become strong individuals and as citizens who can build a nation into a nation of strong character. In developing character education, students should not only teach theoretically, but rather focus on the formation of comprehensive character values that touch on the affective and psychomotor aspects. The family environment is also a determinant of self-development through character education, in addition to the school and community environment. If character education is continuously applied to students, then one day it can become an example and role model for future generation with strong character. ${ }^{14}$ To instill character education, it requires the quality of the education process and management which at least accommodates the following matters: 1) management steps; 2) implementation strategy; 3) readiness of education and educational human resources; 4) indicators of

12 Gurniawan Kamil P, "Pembentukan Karakter Melalui Pendidikan Sosiologi,” Tingkap, Vol. XI, No. 1 (2015), 65.

${ }^{13}$ Athoillah Islamy, " Dialectic Motivation, Behavior And Spritual Peak Experience In The Perspective of Islamic Psychology," alfuad Journal, Vo.3, No.2 (2019), 36.

14 Jenny Indarstoeti SP, Penanaman Nilai-Nilai Karakter Melalui Implementasi Pendidikan Karakter Di Sekolah Dasar," Prosiding Seminar Nasional Inovasi Pendidikan Inovasi Pembelajaran Berbasis Karakter dalam Menghadapi Masyarakat Ekonomi ASEAN, 291. 
program success; 5) Comprehensive program design containing content and contextual analysis of the educational process; 6) program evaluation and supervision techniques; 7) policy formulation that must support the process of implementing character education. ${ }^{15}$

From the description above it can be concluded that the process of character building carried out on children is an important thing to do early on. Not only that, in the process, it is important to involve all parties, namely family, community and school with their complementary tasks.

Reflections on the Values of Social Education in Surah AtTaubah verses 71-72

In its application, the education process is an activity or process of transforming values from educators to students that is carried out in a structured and programmed manner and is ongoing, both carried out in formal and non-formal educational institutions. It must be realized that educational activities have an orientation in order to shape the personality traits of individual students who are good for their lives, both for personal life, society and the natural surroundings. Education is also a process that has the aim to create certain patterns of behavior in certain children or people. ${ }^{16}$ From this it can be understood that educational activities are structured, programmed and systematic activities or activities in which there are responsibilities and orientations in the framework of building, fostering and developing the quality of character of human personality who are knowledgeable and virtuous.

Before the author elaborates on the values of social education that can be extracted from the at-Taubah verses 71-72, here the writer will present the Arabic text editor and the translation of the at-Taubah verses 71-72 which is the focus of the verse object in the discussion of this study, as follows.

15 Abdul Jalil, "Karakter Pendidikan untuk Membentuk Pendidikan Karakter," Nadwa : Jurnal Pendidikan Islam, Vol. 6, No.2, (2012), 183.

${ }^{16}$ Nurul Istiani, Athoillah Islamy, "Objektifikasi Nilai-Nilai Psikosufistik dalam Pendidikan Spritual," Hikamtuna, Vol.4, No.2 (2018), 235. 
"And those who believe, men and women, some of them (are) helping others. they command (do) those who are ma'ruf, prevent from evil, establish prayers, perform alms and they obey Allah and His Messenger. they will be given mercy by God; Truly Allah is Mighty, Wise. Allah promises believers, men and women, (will get) heaven beneath which rivers flow, eternal them in it, and (gets) good places in heaven 'Adn. and Allah's wisdom is greater; that is great luck".

The surah at-Taubah verses 71-72 were revealed without precedence because in other words it does not have asbabunnuzul. But overall the letter at-Taubah was revealed after the Tabuk war, the final war that was followed by the Messenger of Allah, in which the war was fought during the summer and was difficult. At that time there were signs of the hypocrisy of the previous hypocrites. ${ }^{17}$ Therefore, the author does not describe comprehensively historicity related to the chronology of the letter's descent

There are at least four values of social education that can be extracted from the letter at-taubah verses 71-72. In this case the writer will explain through the foothold of explanation by several commentators. Further explanation, as follows.

First, Attitudes Please Help (Ta'awun). Please help (ta'awun) is one of the important needs in life. This is because no one can bear the burden of living alone without the help of others. With a spirit of help, welfare and benefit can be evenly distributed among the community. In this case, Allah Almighty commands his servants to help one another in good, and forbids mutual help in evil as in Surah al-Maidah verse 2:

And please help you in doing righteousness and piety, and do not help in committing sins and transgressions, And fear you Allah. Indeed, Allah is severely tortured."

Al-Qurtubi, ${ }^{18}$ declare verse 2 of Surah al-Maidah is God's command to all beings to help one another over virtue and piety, or to respect some with others. However, according to this verse

\footnotetext{
${ }^{17}$ Ahmad Mustafa Al-Maragi, Tafsir Al-Maragi, ed. oleh Herry Noer (Semarang: CV. Toha Putra Semarang, 1992), 76.

${ }^{18}$.Read Az-Zarkali, Al-A'lam (5/322)."
} 
not every form of help is good, but some are not good. Good help is when it leads to goodness and piety according to religious instructions. Whereas help with regard to sin and enmity includes matters that are prohibited by religion. Free help is carried out with anyone (including non-Muslims), as long as it does not involve matters of faith and worship. In the creed and worship there is no compromise between religions with one another. ${ }^{19}$ This mutual assistance helps people to realize people as social beings. ${ }^{20}$ From this it can be understood that the attitude of helping is part of the values of social education. Not only that, the attitude of helping is inclusive, open to anyone, not only to fellow Muslims.

Second, Amar Makruf Nahi Munkar. Amar ma'ruf means to order people to believe in Allah, His Messenger and carry out His Shari'a. Nahi munkar means to prevent polytheism, to deny the Prophet, and to prevent from what is forbidden by Him. The role of amar makruf nahi mungkar is very important and becomes the main pillar of Islamic society. The important role of amar makruf nahi munkar is increasingly clear in several verses, including: 1) QS. [3]: 104, which speaks of the gate of fortune; 2) QS. [3]: 110 who spoke about the characteristics of the best people; 3) QS. [3]: 114, who spoke of the building of commendable morals; 4) QS. [7]: 157, which speaks of the noble duties of the prophets; 5) QS. [9]: 71, which speaks of the cause of the fall of grace; 6) QS. [22]: 41, which speaks of the qualities of a believer. While the way to do the good deeds of mungkar nahi mungkar, Muslims can refer to paragraph: 1) QS. [32]: 17; 2) QS. [33]: 21; 3) QS. [68]: 4; 4) QS. [3]: 159; 5) QS. [16]: 125. The existence of amar makruf nahi munkar can be part of the values of social education in order to realize the spirit of humanism and liberation in the context of social life.

Third, Social Solidarity. Social solidarity is an emotional and moral feeling that is formed in relationships between individuals or groups based on mutual trust, common goals and ideals, solidarity and a sense of struggle. The

\footnotetext{
${ }^{19}$ Al-Jumhuri, Belajar Aqidah Akhlak. 213.

${ }^{20}$ Samsul Arifin, Pendidikan Agama Islam (Yogyakarta: CV. Budi Utama, 2018).85.
} 
existence of an attitude of solidarity between humans can unite hearts and eliminate the malice between them. This point is implied in the word of God in verse al-Imron verse 103:

"And hold fast all of you to the rope (religion) of Allah Most High, and don't divorce you,"

In addition to surah al-Imron verse 103 above, there are also other verses which emphasize the existence of an attitude of solidarity for fellow believers (believers), namely surah alHujarat verse 10:

""Truly believers are brothers,"

From the description above it can be understood that the attitude of solidarity is an important element that can be used as values and spirit in social life.

Last, Brotherhood. One of the most important concepts in the Islamic social system ${ }^{21}$ is the concept of ukhuwwah (brotherhood), both brotherhood and brethren of the same faith, and fellow human beings. Brotherhood is a deep psychiatric bond of affection, love, and respect for everyone who is bound by Islamic covenant creeds, faith and piety. This true brotherhood gives birth to noble feelings in the Muslim soul, such as mutual help, putting others first, loving one another, and giving forgiveness. Examples of brotherhood in Islam can be through zakat worship. Through zakat instruments can maintain the balance of society from poverty and hedonist life on the other hand. In other words zakat is a form of social concern for individuals, a collective brotherhood towards the proletariat, and reflects the attention of all components of society towards the act of dividing and divorcing. ${ }^{22}$

Objectification of Islamic Social Education Values for Children

The existence of a child is an individual who has a variety of potentials that he can manifest in the context of social life. However, it is important to understand that children born do not yet have the potential for social attitudes. In a sense, he does not

21 RI, Perpustakaan Nasional. Tafsir Al-Quran Tematik Tanggung Jawab Sosial. Diedit oleh Muchlis M. Hanafi. Jakarta: Lajnah Pentashihan Mushaf Al-Qur'an, 2011, 54.

${ }^{22}$ Ahzami Samiun Jazuli, Kehidupan dalam Pandangan AlQur'an (Jakarta: Gema Insani, 2006). h. 226-227. 
yet have the ability to get along with others. To achieve social maturity, children must learn how to adjust to others. This ability is obtained by children through various opportunities or experiences of getting along with people in their environment, whether parents, siblings, peers or other adult. ${ }^{23}$ From this it can be understood that the formation of social attitudes in children is a matter that is not natural but through the process of formation in social interaction.

It is important to understand that social development is the achievement of maturity in social relations. Therefore, the role of educators in children social education can be realized in a variety of ways, such as guiding, fostering and training children to socialize to become mature people who gradually socialize. Given in the context of early childhood social development there are diverse characters as follows: birth to age three years react to other people, ages 3-4 years; becoming more self-aware, ages 56 years; states rigid ideas about the role of sex. 78 years old; more often compete with peers. Factors that influence social development of children : family environmental factors: family status, family integrity, attitudes and habits of parents; factors from outside the home; influence factors of the child's social experience. Teacher's attempt to develop children social: provide a decorative angle; for children aged 3 years, good play equipment must be sufficient; use puppets to model the appropriate technique in entering a playgroup; encourage children to make as many decisions as possible; model empathy and care for behavior and encourage children to do this behavior; Role playing is a solution for solving problems in interactions. ${ }^{24}$ From this it follows that social formation in early children education can be adjusted to various stages in the

${ }^{23}$ Musyarofah, "Pengembangan Aspek Sosial Anak Usia Dini Di Taman Kanak-Kanak ABA IV Mangli Jember Tahun 2016," INJECT: Interdisciplinary Journal of Communication, Vol. 2, No.1 (2017), 100-102.

${ }^{24}$ Farida Mayar, "Perkembangan Sosial Anaku Usia Dini Sebagai Bibit Untuk Masa Depan Bangsa," Jurnal Al-Ta'lim, Jilid 1, Nomor 6 November 2013, hlm. 459-464 464-465 
development of children's emotional character based on age factors.

In the context of Islamic social education, various social values that are contained in the letter at-Taubah verses 71-72, such as the attitude of help, brotherhood, social solidarity and amar makruf nahi mungkar can be instilled in early chilhood's social education according to the development of their age. Given the child's social development is the development of behavior in children where he adjusts to the rules that apply in the community environment. In other words, social development is a child's learning process in adjusting to norms, morals and traditions in a group. Various values of Islamic social education can be instilled in children through social interaction in family life and school. ${ }^{25}$ Therefore, the inculcation of various values of Islamic social education in children is a shared responsibility, that is the responsibility of parents at home or teachers at school. According to

Abdullah Nāșih 'Ulwān as quoted by Eus Cici and Husni states that there are four important things in the context of Islamic education for early childhood, among others as follows, instilling a noble mentality, paying attention to the rights of others, commitment to social ethics in general, critical and social supervision. ${ }^{26}$ These four things can be said to be synergistic with the various values of social education in Surah At-Tawbah verses 71-72. This we can see as follows.

The First, the spirit of cultivating a noble mentality. This spirit can be realized in the context of instilling brotherly values and please help the child. This was caused. the values of Islamic teachings cover and touch all aspects of human life that are very complex. The perfection of Islamic teachings is able to provide a positive response to all problems in aspects of human life and society. Every human who lives in a society wants to live

${ }^{25}$ Femmi Nurmalitasari "Perkembangan Sosial Emosi pada Anak Usia Prasekolah" Buletin Psikologi, Vol.23, No.2 (2015), 104.

${ }^{26}$ Eus Cici Nurunisa, Husni, "Nilai-Nilai Pendidikan Sosial Perspektif "Abdullah Nasih Ulwan NĀṢIH dan Relevansinya Terhadap Tujuan Pendidikan Nasional," Tarbiyah Aulad, Vol.1 No.1 (2016), 16-17. 
peacefully, safely, peacefully, full of happiness and prosperity. Many of the suggestions contained in the Qur'an require that humans unite in togetherness and deliberation that is based on togetherness, justice and truth, helping one another, helping one another, advising one another and so on. Based on this, the Qur'an regulates this problem in a verse that shows ukhuwah Islamiyah. This brotherhood in Islam connects bonds in terms of creed, equality of trust which is also strengthened by the same spirit and spirit of obedience to the creator of this universe. ${ }^{27}$ Such understanding makes it necessary for parents and educators to be able to direct the values of goodness, peace to children in their social interactions or relationships.

Second, the spirit of attention to the rights of others and commitment to social ethics. This spirit can also be realized through the inculcation of the value of social solidarity. Given the teachings of Islam there are many commands and suggestions that ask people to do good to others, improve relations with others, love and love others, are prohibited from deciding solidarity, even Islam teaches people to love others as they love themselves. Besides these commands, the teachings of Islam also instructed his people to carry out certain rituals or worship as proof of devotion to God. Among the rituals it is associated with social action. All the commands of the above rituals if done repeatedly, will make Muslims often gather, interact with each other, understand each other. With frequent gatherings to perform religious rituals it will cause vibrations of the soul among fellow members of worship groups, happy and sad together, have the same goals and ideals, the same beliefs, and feel the same senentungan. Then finally it will bring feelings, feelings of sympathy, identification, a feeling of belonging, a sense of love between people. ${ }^{28}$ Based on the awareness of the importance of the attitude of solidarity in this

${ }^{27}$ Ikhwan Hadiyin, "Konsep Pendidikan Ukhuwah : Analisa Ayat-Ayat Ukhuwwah Dalam al-Qur'an,"al-Qalam, Vol.33, No.2 (2016), 38.

28 Kamirudin, "Agama dan Solidaridaritas Sosial :Pandangan Islam Terhadap Pemikiran Sosiologi Emile Durkheim," Al-Fikra: Jurnal Ilmiah Keislaman, Vol. 5, No.1,(2006),82 
life, then the inculcation of the values of social solidarity to children is important to implement early on.

Third, the spirit of critical and social supervision can berealized by instilling the value of amar makruf nahi munkar. Understanding the meaning of amar ma'ruf nahi munkar is the best way to unite in the truth under the auspices of the Koran and His Sunnah, namely by becoming a people who call for all forms of the goodness of the world and the hereafter according to the message contained in the verse al-Qur'an, and calls for the obligation of encouraging people to do right and prevent wrong doing. In this case Muhammad Asad as quoted by Kusnadi and Zulhilmi states that al-ma'ruf are all the commands of Allah that lead to the truth in accordance with the Shari'a, and al-munkar are all acts that are forbidden by Allah which lead to the wrong path contrary to the Shari'a . Because all things related to good in the form of actions that lead to the right path and all actions that lead to evil are mistakes. Those who practice that principle are the ones who get perfect luck. ${ }^{29}$ The cultivation of the values of amar makruf nahi munkar can be taught to children, namely by getting used to instructing or reminding their friends in positive actions and leaving negative actions.

\section{Conclusion}

Based on the discussion, it can be concluded that the letter at-Taubah verses 71-72 contains the values of social education as follows. First, attitude please help. This attitude can give birth to the nature of empathy, care so that the bond of brotherhood, togetherness, and peace in social life, Secondly, amar makruf nahi munkar, which invites to goodness and prevents ignorance between people. This becomes the value of social education because of the awareness of each member people pay attention to themselves and their surroundings, so that peace can be realized. Third, socsal solidarity. This attitude can unite the heart and eliminate malice, the Fourth. brotherhood is one of the values of social education that can describe our authenticity as social beings. The four values of social education

${ }^{29}$ Kusnadi, Zulhilmi Zulkarnain, "Makna Amar Makruf Nahi Munkar Menurut Muhammad Asad dalam Kitab The Message of The Qur'an,"Wardah, Vol.18, No.2 (2017), 114 
can be actualized in the context of the planting of social education in children through various things, among others, the cultivation of a noble mentality in children can be realized in the planting of brotherly values and help children. Furthermore, the cultivation of a spirit of attention to the rights of others and a commitment to social ethics can be realized through the inculcation of the value of social solidarity. Then, inculcation of critical and social supervision can be realized by instilling the value of amar makruf nahi munkar.

\section{References}

Arifin, Samsul. Pendidikan Agama Islam. Yogyakarta: CV. Budi Utama, 2018.

As-Sirjani, Raghib. Sumbangan Pradaban Islam pada Dunia. Jakarta: Pustaka Kautsar, 2009.

Cici, Euis Nurunisa, Husni, "Nilai-Nilai Pendidikan Sosial Perspektif 'Abdullah Nasih Ulwan NĀṢIH dan Relevansinya Terhadap Tujuan Pendidikan Nasional," Tarbiyah Aulad, Vol.1 No.1 (2016).

Fardus, "Model Pendidikan Nilai Sosial Budaya dalam Keluarga dan Lingkungan Manusia Bajo di Bajo," Educationist, Vol. IV No. 1 (2010), 58.

Istiani, Nurul, Athoillah Islamy, "Objektifikasi Nilai-Nilai Psikosufistik dalam Pendidikan Spritual," Hikamtuna, Vol.4, No.2 (2018), 235.

Gurniawan Kamil P, "Pembentukan Karakter Melalui Pendidikan Sosiologi," Tingkap, Vol. XI, No. 1 (2015).

Gunawan, Imam. Metode Penelitian Kualitatif dan Teori. Jakarta: Bumi Aksara, 2013.

Hadi, Saiful. Shalat Samudra Hikmah. Jakarta: Wahyu Qolbu, 2016.

Hafidhuddin, Didin. Zakat dalam Perekonomian Modern. Jakarta: Gema Insani, 2002.

Halid Hanafi, La Adu, Zainudin. Ilmu Pendidikan Islam. Yogyakarta: CV. Budi Utama, 2018.

Hamka. Tafsir Al-Azhar. Jakarta: Pustaka PanjiMas, 1985.

Harmadi, Hamid. Pengantar Pendidikan Era Globalisasi. Diedit oleh Masri Sarep Putra. AnImage, 2016.

Hadiyin, Ikhwan "Konsep Pendidikan Ukhuwah : Analisa Ayat- 
Ayat Ukhuwwah Dalam al-Qur'an,"al-Qalam, Vol.33, No.2 (2016).

Islamy, Athoillah “ Dialectic Motivation, Behavior And Spritual Peak Experience In The Perspective of Islamic Psychology," alfuad Journal, Vo.3, No.2 (2019).

Indarstoeti SP, Jenny, Penanaman Nilai-Nilai Karakter Melalui Implementasi Pendidikan Karakter Di Sekolah Dasar," Prosiding Seminar Nasional Inovasi Pendidikan Inovasi Pembelajaran Berbasis Karakter dalam Menghadapi Masyarakat Ekonomi ASEAN.

Jazuli, Ahzami Samiun. Kehidupan dalam Pandangan AlQur'an. Jakarta: Gema Insani, 2006.

Jalil, Abdul, "Karakter Pendidikan untuk Membentuk Pendidikan Karakter," Nadwa : Jurnal Pendidikan Islam, Vol. 6, No.2, (2012).

Joesoef, Soeleman. Konsep Dasar Pendidikan Luar Sekolah. Jakarta: Bumi Aksara, 1992.

Kamirudin, "Agama dan Solidaridaritas Sosial :Pandangan Islam Terhadap Pemikiran Sosiologi Emile Durkheim," AlFikra: Jurnal Ilmiah Keislaman, Vol. 5, No.1,(2006).

Kusnadi, Zulhilmi Zulkarnain, "Makna Amar Makruf Nahi Munkar Menurut Muhammad Asad dalam Kitab The Message of The Qur'an," Wardah, Vol.18, No.2 (2017).

Masdub. Sosiologi Pendidikan Agama Islam. Yogyakarta: Aswaja Pressindo, 2015.

_. Sosiologi Pendidikan Agama Islam. Diedit oleh Abdul Khaliq. Yogyakarta: Aswaja Pressindo, 2015.

Mayar, Farida, "Perkembangan Sosial Anaku Usia Dini Sebagai Bibit Untuk Masa Depan Bangsa," Jurnal Al-Ta'lim, Jilid 1, Nomor 6 November 2013.

Nurmalitasari, Femmi "Perkembangan Sosial Emosi pada Anak Usia Prasekolah" Buletin Psikologi, Vol.23, No.2 (2015).

Musyarofah, "Pengembangan Aspek Sosial Anak Usia Dini Di Taman Kanak-Kanak ABA IV Mangli Jember Tahun 2016," INJECT: Interdisciplinary Journal of Communication, Vol. 2, No.1 (2017).

Mudzakir, Abdul Mujib Jusuf. Ilmu Pendidikan Islam. Jakarta: Pranada Media, 2006.

Neolaka, Amos. Landasan Pendidikan. Depok: PT Kharisma 
Putra Utama, 2017.

RI, Kementrian Agama. Amar Makruf Nahi Mungkar. Jakarta: Lajnah Pentashih Mushaf Al-Qur'an, 2013.

RI, Perpustakaan Nasional. Tafsir Al-Quran Tematik Tanggung Jawab Sosial. Diedit oleh Muchlis M. Hanafi. Jakarta: Lajnah Pentashihan Mushaf Al-Qur'an, 2011.

Rifa'i, Muhammad. Sosiologi Pendidikan. Jogjakarta: Ar-Ruzz Media, 2011.

Ulwan, Abdullah Nashih. Pendidikan Anak dalam Islam. Jakarta: Pustaka Amani, 2002.

Undang Undang Republik Indonesia No 20 tahun 2003 tentang Sistem Pendidikan Nasional \& Undang undang Nomer 14 Tahun 2005 tentang Guru dan Dosen. Jakarta: Visimedia, 2007.

Widiyani, Rosmha. "Viral siswa pukul cleaning service, Psikologi pengaruh singgung kesalahan pola asuh,." detik.com, 2019. 